DR. LAURENCE FELDMEYER (Orcid ID : 0000-0002-4858-5525)

DR. SIMONE CAZZANIGA (Orcid ID : 0000-0001-8161-6138)

PROF. LUCA BORRADORI (Orcid ID : 0000-0003-0424-6297)

DR. HELMUT BELTRAMINELLI (Orcid ID : 0000-0002-8179-1793)

Article type : Letter to Editor

\title{
Oral lichen planus and oral lichenoid lesions - an analysis of clinical and histopathological
} features

Running head: Oral lichen planus versus oral lichenoid lesions

L. Feldmeyer ${ }^{1}$, V.G. Suter ${ }^{2}$, C. Oeschger ${ }^{2}$, S. Cazzaniga ${ }^{1,3}$, M. M. Bornstein ${ }^{4}$, D. Simon ${ }^{1}$, L. Borradori $^{1}, \mathrm{H}$. Beltraminelli ${ }^{1}$

1Department of Dermatology, Inselspital, Bern University Hospital, University of Bern, Switzerland ${ }^{2}$ Department of Oral Surgery and Stomatology, School of Dental Medicine, University of Bern, Bern, Switzerland

${ }^{3}$ Centro Studi GISED, Bergamo 24122, Italy

${ }^{4}$ Applied Oral Sciences, Faculty of Dentistry, The University of Hong Kong, Prince Philip Dental Hospital, Sai Ying Pun, Hong Kong SAR, China

Corresponding author: Laurence Feldmeyer, MD, PhD, Department of Dermatology, Inselspital, Bern University Hospital, University of Bern, Switzerland

Telephone: +41 (0)31 63266 22; Fax: +41(0)31 63222 33; Email: laurence.feldmeyer@insel.ch

\section{Funding sources: None}

Conflicts of interest: None declared

This article has been accepted for publication and undergone full peer review but has not been through the copyediting, typesetting, pagination and proofreading process, which may lead to differences between this version and the Version of Record. Please cite this article as doi: 10.1111/JDV.15981

This article is protected by copyright. All rights reserved 
IRB approval status: Reviewed and approved by the ethics committee of the Canton of Bern (KEK192/10)

Word number: 607

Tables number: 2

References: 10

This article is protected by copyright. All rights reserved 
In the oral mucosa, a precise classification of inflammatory lesions with a histopathological lichenoid inflammation represents a diagnostic challenge. Oral lichen planus (OLP) and oral lichenoid lesions (OLL) share several clinical and histopathological characteristics, therefore it is often difficult to distinguish between them. However, considering that the pathophysiologic mechanisms and the treatment approach of OLP and OLL are different, an early distinction $\theta$ f between these two diseases is meaningful.

Lichen planus (LP) is an idiopathic inflammatory disease of the skin, hair follicle, nails, and mucous membranes ${ }^{1}$. Cutaneous lichen planus (CLP) was observed in up to $20 \%$ of an OLP population ${ }^{2}$, and more than $50 \%$ of patients with CLP have concomitant OLP3.

The diagnosis of an OLP based on clinical and histopathological features has been proposed by the WHO collaborating center for oral precancerous lesions, adapted according to van der Meij and van der Waal ${ }^{4,5}$. Clinically, it is characterized by the presence of oral bilateral, symmetrical lesions, and of slightly raised gray-white lines (Wickham's Striae) alone, or together with plaque-like, atrophic, erosive or bullous lesions. Histologically, a lichenoid inflammation may be observed. There is another group of oral inflammatory lesions with both clinically, and histopathologically similar characteristics as OLP, but are not compatible with OLP and are typically associated with an attributable etiological factor. Different terms were used to name them ${ }^{5-7}$ : lichen planus-like lesions, oral lichenoid lesions, oral lichenoid contact lesions, oral lichenoid drug reactions, oral lichenoid tissue reactions, lichenoid contact stomatitis. The most commonly used term is oral lichenoid lesions (OLL). The absence of a clearly attributable etiological factor is an important criterion distinguishing OLP from OLL ${ }^{5-7}$. In the literature, the following features distinguishing OLL from OLP have been described: a perivascular (instead of band-like) pattern of inflammation, a substantial number of plasma cells, eosinophils, neutrophils, an interruption of the stratum granulosum, presence of focal parakeratosis, and scattered apoptotic keratinocytes in all epidermal layers ${ }^{8}$.

In a monocentric, retrospective, interdisciplinary study we have analyzed 9 clinical and 6 histopathological characteristics in 115 patients with a histologically confirmed oral lichenoid inflammation and a possible diagnosis of OLP or OLL. All consecutive cases were retrieved from the archives of our tertiary referral center during the 26-months study period. The diagnosis of OLL was based on the following criteria: clinically presence of reticular, and/or oral plaque-like, and/or atrophic, and/or erosive OLP-like-lesions, but without widespread distribution in the oral cavity ${ }^{5-7}$. Furthermore, the patients had no signs of a CLP. Histologically all had a acanthotic epithelium with 
saw-tooth rete ridges, a liquefactive degeneration of the basal cells, colloid bodies, and band-like histio-lymphocytic infiltrates.

We identified 86 patients with the criteria of OLP, and 29 with OLL. In both groups, we observed a majority of women, 60 women and 26 men with OLP, 23 women and 6 men with OLL. The mean age was similar for both groups, 60 years in patients with OLP and 62 years for OLL.

Clinically we found only one significant difference, namely the presence of amalgam filling material was more frequently present and in direct contact with OLL than with OLP $(p=0.002)$ (Table 1). OLP lesions were mainly localized on the buccal mucosa (87\%). Lesions on the dorsum of the tongue (OLP $n=15$; OLL $n=1$ ) and of the lip (OLP $n=5$; OLL $n=0$ ) were almost only seen in OLP (Table 2). Histologically there was no significant difference. Similarly as previously reported ${ }^{8-10}$, we saw more eosinophils in OLL than in OLP.

The distinction between OLL and OLP remains a challenge as both diseases share many characteristics. To get a more accurate diagnosis, a combined, thorough clinical and histopathological evaluation by an expert would be necessary.

This article is protected by copyright. All rights reserved 


\section{References}

1. Le Cleach L, Chosidow O. Clinical practice. Lichen planus. N Engl J Med. 2012;366(8):723732.

2. Silverman S, Gorsky M, Lozada-Nur F. A prospective follow-up study of 570 patients with oral lichen planus: persistence, remission, and malignant association. Oral Surg Oral Med Oral Pathol. 1985;60:30-34.

3. Carbone M, Arduino PG, Carrozzo M, et al. Course of oral lichen planus: a retrospective study of 808 northern Italian patients. Oral Dis. 2009;15:235-243.

4. van der Meij EH, van der Waal I. Lack of clinicopathologic correlation in the diagnosis of oral lichen planus based on the presently available diagnostic criteria and suggestions for modifications. $J$ Oral Pathol Med. 2003;32:507-512.

5. van der Waal I. Oral lichen planus and oral lichenoid lesions; a critical appraisal with emphasis on the diagnostic aspects. Med Oral Patol Oral Cir Bucal. 2009;14:E310-314.

6. Al-Hashimi I, Schifter M, Lockhart PB, et al. Oral lichen planus and oral lichenoid lesions: diagnostic and therapeutic considerations. Oral Surg Oral Med Oral Pathol Oral Radiol Endod. 2007;103 Suppl:S25.e1-12.

7. Alrashdan MS, Cirillo N, McCullough M. Oral lichen planus: a literature review and update. Arch Dermatol Res 2016;308:539-551.

Periodontol 2000. 2019;80:105-125.

8. Mravak-Stipetić M, Lončar-Brzak B, Bakale-Hodak I, et al. Clinicopathologic correlation of oral lichen planus and oral lichenoid lesions: a preliminary study. ScientificWorldJournal. 2014;2014:746874.

9. Reddy DS, Sivapathasundharam B, Saraswathi TR, et al. Evaluation of mast cells, eosinophils, blood capillaries in oral lichen planus and oral lichenoid mucositis. Indian $J$ Dent Res. 2012;23:695-696.

10. Thornhill MH, Sankar V, Xu X-J, et al. The role of histopathological characteristics in distinguishing amalgam-associated oral lichenoid reactions and oral lichen planus. $J$ Oral Pathol Med. 2006;35:233-240.

This article is protected by copyright. All rights reserved 


\section{Table Legends}

Table 1:

Presence and characteristics of dental materials in the study population, overall and by kind of diagnosis

Table 2: Clinical characteristics of the lesions, overall and by kind of diagnosis

This article is protected by copyright. All rights reserved 
Table 1 - Presence and characteristics of dental materials in the study population, overall and by kind of diagnosis

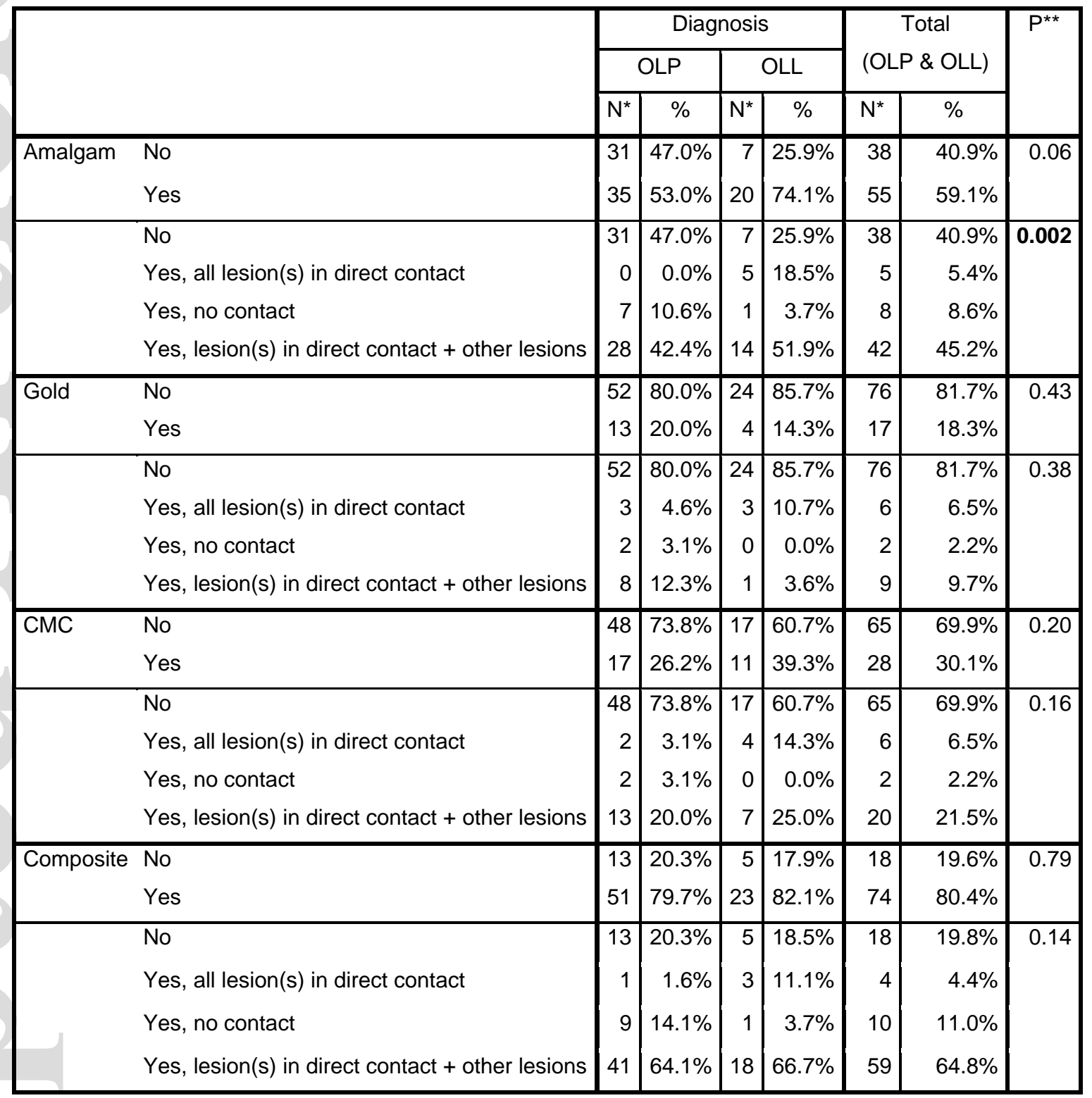

* Numbers may not add up to the total due to missing data

** Pearson's $\mathrm{X}^{2}$ test, or Fisher's exact test where required bold = significant

CMC: ceramo-metal crown 
Table 2 - Clinical characteristics of the lesions, overall and by kind of diagnosis

\begin{tabular}{|c|c|c|c|c|c|c|c|c|}
\hline & \multicolumn{4}{|c|}{ Diagnosis } & \multirow{2}{*}{\multicolumn{2}{|c|}{$\begin{array}{c}\text { Total } \\
\text { (OLP \& } \\
\text { OLL) }\end{array}$}} & \multirow[t]{3}{*}{$\mathrm{P}^{\star}$} \\
\hline & & \multicolumn{2}{|r|}{ OLP } & \multicolumn{2}{|r|}{ OLL } & & & \\
\hline & & $\mathrm{N}$ & $\%$ & $N$ & $\%$ & $\mathrm{~N}$ & $\%$ & \\
\hline Type of lesion in patients & $\begin{array}{l}\text { Only reticular and/or only } \\
\text { plaque-like } \\
\text { Mixed reticular/plaque-like } \\
\text { \& erosive }\end{array}$ & 54 & $\begin{array}{l}37.2 \% \\
62.8 \%\end{array}$ & 19 & $\begin{array}{l}34.5 \% \\
65.5 \%\end{array}$ & 73 & $\begin{array}{l}36.5 \% \\
63.5 \%\end{array}$ & 0.79 \\
\hline \multicolumn{2}{|c|}{$\begin{array}{l}\text { Localisation of lesions (more than } \\
\text { one lesions per patient) }\end{array}$} & & & & & & & \\
\hline Buccal mucosa & No & 4 & $4.7 \%$ & 5 & $17.2 \%$ & 9 & $7.8 \%$ & 0.003 \\
\hline \multirow[t]{2}{*}{ involvement } & Unilateral & 7 & $8.1 \%$ & 7 & $24.1 \%$ & 14 & $12.2 \%$ & \\
\hline & Both & 75 & $87.2 \%$ & 17 & $58.6 \%$ & 92 & $80.0 \%$ & \\
\hline \multirow{3}{*}{$\begin{array}{l}\text { Tongue border } \\
\text { involvement }\end{array}$} & No & 60 & $69.8 \%$ & 17 & $58.6 \%$ & 77 & $67.0 \%$ & 0.18 \\
\hline & Unilateral & 9 & $10.5 \%$ & 7 & $24.1 \%$ & 16 & $13.9 \%$ & \\
\hline & Both & 17 & $19.8 \%$ & 5 & $17.2 \%$ & 22 & $19.1 \%$ & \\
\hline \multirow{3}{*}{$\begin{array}{l}\text { Dorsum tongue } \\
\text { involvement }\end{array}$} & No & 68 & $79.1 \%$ & 27 & $93.1 \%$ & 95 & $82.6 \%$ & 0.14 \\
\hline & Unilateral & 3 & $3.5 \%$ & 1 & $3.4 \%$ & 4 & $3.5 \%$ & \\
\hline & Both & 15 & $17.4 \%$ & 1 & $3.4 \%$ & 16 & $13.9 \%$ & \\
\hline \multirow{3}{*}{$\begin{array}{l}\text { Palate } \\
\text { involvement }\end{array}$} & No & 74 & $86.0 \%$ & 26 & $89.7 \%$ & 100 & $87.0 \%$ & 0.37 \\
\hline & Unilateral & 3 & $3.5 \%$ & 2 & $6.9 \%$ & 5 & $4.3 \%$ & \\
\hline & Both & 9 & $10.5 \%$ & 1 & $3.4 \%$ & 10 & $8.7 \%$ & \\
\hline \multirow{3}{*}{$\begin{array}{l}\text { Mouth floor } \\
\text { involvement }\end{array}$} & No & 82 & $95.3 \%$ & 28 & $96.6 \%$ & 110 & $95.7 \%$ & 0.18 \\
\hline & Unilateral & 0 & $0.0 \%$ & 1 & $3.4 \%$ & 1 & $0.9 \%$ & \\
\hline & Both & 4 & $4.7 \%$ & 0 & $0.0 \%$ & 4 & $3.5 \%$ & \\
\hline \multirow[t]{2}{*}{ Lips involvement } & No & 81 & $94.2 \%$ & 29 & $100.0 \%$ & 110 & $95.7 \%$ & 0.33 \\
\hline & Yes & 5 & $5.8 \%$ & 0 & $0.0 \%$ & 5 & $4.3 \%$ & \\
\hline \multirow{7}{*}{$\begin{array}{l}\text { Gingival } \\
\text { involvement }\end{array}$} & No & 33 & $38.4 \%$ & 10 & $34.5 \%$ & 43 & $37.4 \%$ & 0.48 \\
\hline & Anterior region 13-23 & 1 & $1.2 \%$ & 1 & $3.4 \%$ & 2 & $1.7 \%$ & \\
\hline & Posterior region $24-28$ & 1 & $1.2 \%$ & 0 & $0.0 \%$ & 1 & $0.9 \%$ & \\
\hline & Posterior region 14-18 & 4 & $4.7 \%$ & 2 & $6.9 \%$ & 6 & $5.2 \%$ & \\
\hline & Generalized & 32 & $37.2 \%$ & 7 & $24.1 \%$ & 39 & $33.9 \%$ & \\
\hline & $\begin{array}{l}\text { Several individual } \\
\text { locations }\end{array}$ & 3 & $3.5 \%$ & 2 & $6.9 \%$ & 5 & $4.3 \%$ & \\
\hline & Bilateral posterior & 12 & $14.0 \%$ & 7 & $24.1 \%$ & 19 & $16.5 \%$ & \\
\hline
\end{tabular}

* Pearson's $X^{2}$ test, or Fisher's exact test where required 